University of Michigan Law School

University of Michigan Law School Scholarship Repository

Articles

Faculty Scholarship

1922

\title{
The Kansas Declaratory Judgment Act in Operation
}

Edson R. Sunderland

University of Michigan Law School

Available at: https://repository.law.umich.edu/articles/1595

Follow this and additional works at: https://repository.law.umich.edu/articles

Part of the State and Local Government Law Commons

\section{Recommended Citation}

Sunderland, Edson R. "The Kansas Declaratory Judgment Act in Operation." Mich. L. Rev. 20 (1922): 775-7.

This Response or Comment is brought to you for free and open access by the Faculty Scholarship at University of Michigan Law School Scholarship Repository. It has been accepted for inclusion in Articles by an authorized administrator of University of Michigan Law School Scholarship Repository. For more information, please contact mlaw.repository@umich.edu. 
The, Kansas Declaratory Judgament Act in Operation.-Statutes of Kansas authorized cities of the first class to carry out works of internal improvement and provide for payment of the cost thereof by issuing bonds of the city running no longer than ten years and bearing interest not exceeding five per cent. When conditions following the war made the marketing of five per cent bonds impossible at a price anywhere near par, the legislature enacted a new law authorizing the issuance of internal improvement bonds at six per cent interest, but requiring every such bond to contain a privilege of prepayment after five years from date. 
The city of Kansas City desired to undertake some internal improvements, but the money market had so far approached normal that five per cent bonds could be sold at a premium. The officers of the city did not know whether the effect of the new law was to repeal the old, thus making the prepayment privilege a necessary term in every bond to be issued, or whether it was an additional emergency statute applying only to bonds actually issued bearing interest above five per cent. They were anxious, if possible, to escape the prepayment restriction, for the privilege of shorttime prepayment was shown to operate in the sale of bonds as a discount of one-half of one per cent, which would entail a heavy loss upon the city. The state officers, who were charged with the enforcement of the state law, were equally anxious to prevent the city from doing this if it was in fact illegal.

To ascertain the rights of the city in the premises the state applied to the district court for a declaration as to the rights of the city under the statutory restrictions imposed by the state, in an action brought against the city for that purpose, and the court promptly declared that the old law was not repealed and the city might issue five per cent bonds without inserting the provision for prepayment after five years.

Justice Burch, writing the opinion of the court, makes the following interesting comment upon the practical effectiveness of the new Declaratory Judgment law. He says:

"The proceedings in this case serve to illustrate the operation of the declaratory judgment act. Execution of the city's internal-improvement program placed it in this dilemma. If privilege of prepayment were not written in the bonds, the city and its officers were exposed to prosecution by the state for abuse of corporate power and violation of law, and the securities might not be marketable. If privilege of prepayment were written in the bonds, a heavy financial burden would be placed on the taxpayers, perhaps unnecessarily. Formerly, the city would have been compelled to choose one course or the other and abide the consequences. The law officers of the state could not give a binding interpretation of the statute, and, because of its ambiguity, could not consent to the course which, the city claimed it was authorized to pursue. Therefore, a controversy existed justiciable under the declaratory judgment act. The action was commenced in the district court on February 7 , I922, and the defendant answered instanter. The cause was heard on the petition and answer and a stipulation that the pleadings stated the facts. The declaration of the district court was rendered on February 7 , and the appeal was lodged in this court on February 10. This court was in session when the appeal was filed. Because of the public importance of the question involved, the cause was advanced for immediate hearing, and on February ro it was submitted for final decision, on oral argument and briefs of counsel which accompanied the appeal papers. The city may now proceed with its improvements without any of the embarrassments and without any of the delay which would have been encountered if the remedy of declaration of right had not been available." 
The case is State of Kansas v. City of Kansas City. The case was actually decided by the Supreme Court within two weeks after it was commenced in the district court. The opinion was filed February 24, 1922, but had not been published at the date of this writing.

E. R. S. 